\title{
Quantitative characteristics of the carcasses of Moxotó and Canindé goats fed diets with two different energy levels
}

\author{
Ana Cristina Chacon Lisboa ${ }^{1}$, Dermeval Araújo Furtado ${ }^{2}$, Ariosvaldo Nunes de Medeiros ${ }^{3}$, \\ Roberto Germano Costa ${ }^{4}$, Rita de Cássia do Egypto Queiroga ${ }^{5}$, Lígia Maria Gomes Barreto ${ }^{1}$
}

${ }^{1}$ Mestranda em Zootecnia UFPB/CCA/Areia.

2 Departamento de Engenharia Agrícola UFCG/CTRNG.

${ }^{3}$ Departamento de Zootecnia UFPB/CCA/Areia.

${ }^{4}$ Centro de Formação de Tecnólogos/UFPB/Bananeiras.

${ }^{5}$ Centro de Ciências e Saúde/UFPB/João Pessoa.

ABSTRACT - The objective of this work was to evaluate the quantitative characteristics of carcasses of Moxotó and Canindé goats finished in feedlots and fed diets of two levels of energy. It was used 40 castrated young goats, 20 from Moxotó breed and 20 from Canindé breed, each one with an average body weight of $15.2 \mathrm{~kg}$. The animals were fed with diets containing 2.20 and 2.71 (Mcal/kg DM). The experimental period lasted 86 days. There was no difference among the barometric measures of Moxotó and Canindé kids. Canindé goats showed higher final weight, higher weight after fasting and higher hot and cold carcass weights when compared to the Moxotó animals. Animals that consumed diets with higher energy level had higher final weight and conformation as well as higher carcass yield. Considering the percentage values of the commercial meat cuts, no difference among treatments was observed. The diet was the factor that most influenced the non-constituent components of the carcass of Moxotó and Canindé goats. In general, animals belonging to the Canindé breed presented higher quantitative characteristics than the Moxotó breed. Supply of diets with higher energetic level (2.71 Mcal/kg DM) for goats from Moxotó and Canindé breeds, in feedlots, favors the production of carcass with higher yields and heavier commercial meat cuts.

Key Words: carcass yield, commercial meat cuts, maniçoba hay, native goat breeds

\section{Características quantitativas da carcaça de caprinos das raças Moxotó e Canindé recebendo dietas com dois níveis de energia}

RESUMO - Objetivou-se avaliar as características quantitativas da carcaça de caprinos Moxotó e Canindé terminados em confinamento e recebendo dietas com dois níveis de energia. Foram utilizados 40 cabritos castrados, com peso médio de 15,2 kg, sendo 20 da raça Moxotó e 20 da raça Canindé, suplementados com dietas contendo 2,20 e 2,71 (Mcal $/ \mathrm{kg} \mathrm{MS}$ ). O período experimental consistiu de 86 dias. Não se constatou distinções entre as medidas barimétricas de cabritos Moxotó e Canindé. Os cabritos da raça Canindé caracterizam-se por apresentar maior peso final, peso vivo pós-jejum e peso de carcaça quente e fria, que animais da raça Moxotó. Os animais que consumiram dietas com maior nível de energia apresentaram maior peso final e conformação, assim como maiores rendimentos de carcaça. Considerando-se os valores percentuais dos cortes comerciais não se observaram distinções entre os tratamentos. A dieta atuou como principal fator de influência sobre os componentes não constituintes da carcaça de caprinos das raças Moxotó e Canindé. De modo geral, caprinos da raça Canindé apresentam características quantitativas de carcaça superior a raça Moxotó. O fornecimento da dieta com maior nível energético (2,71 Mcal/kg MS) para caprinos da Raça Moxotó e Canindé, em confinamento, favorece a produção de carcaças com rendimentos superiores e cortes comerciais mais pesados.

Palavras-chave: cortes comerciais, feno de maniçoba, raças nativas de cabritos, rendimento de carcaça

\section{Introduction}

The development of goat production for slaughter in the northeast region of Brazil is directly related to the incorporation of adequate production techniques, which are necessary for obtaining more effective producing systems. The main alternative for reducing production costs in the raising of goats is the capacity of these animals for digesting fibrous foods (Moron-Fuenmayor \& Clavero, 1999). 
Finishing lambs in feedlots, allied to supplementation the diets of the animals with adequate levels of forage and concentrates, enables the obtainment of a good quality carcass with a better cost-benefit ratio in the production and better profits for the farmer (Cartaxo et al., 2009), thus representing a fundamental strategy for optimizing goat raising for slaughtering in the semi-arid region. According to the recommended values of the NRC (1998), diets with $70 \%$ more concentrates increase the incidence of physiologic disorders in ruminants.

Genotype and nutritional management are the main factors that influence the quality of the carcass (Almeida Jr. et al., 2004). Defining the most appropriate breed and the most adequate techniques for each type of production is fundamental for obtaining profitable and viable productive systems.

This study aimed at evaluating the characteristics of the carcasses of Moxotó and Canindé breed goats raised in a feedlot system and receiving diets with two different levels of metabolizable energy.

\section{Material and Methods}

The experiment was developed at the Estação Experimental de Pesquisa em Pequenos Ruminantes da Universidade Federal da Paraíba, localized in the town of São João do Cariri, in the micro-region of the Occidental Cariri of Paraíba, localized in the town of São João do Cariri, in the micro-region of the Occidental Cariri of Paraíba $\left(7^{\circ} 23^{\prime} 27^{\prime \prime} \mathrm{S} 36^{\circ} 31^{\prime} 58^{\prime \prime} \mathrm{W}\right)$. During the experimental period, the recorded average relative temperature and humidity were $28.11^{\circ} \mathrm{C}$ and $57.41 \%$, respectively.

It was used 40 castrated young goats, in which 20 were Moxotó breed and 20 were Canindé breed, at 5 months of age and an initial weight of $15.2 \pm 1.91 \mathrm{~kg}$. The animals were confined in individual stalls of $3.75 \mathrm{~m}^{2}$ which were covered with ceramic roofing tiles, dirt floors, and furnished with feeding and drinking troughs, for a period not longer than 107 days. During the adaptation period (21 days), the animals were vaccinated, dewormed and given an organic modifier (vitamin and mineral complex). Weighing procedures were performed weekly to monitor their body development.

Diets were isoproteic (Table 1 ) and they were calculated so as to meet the protein and metabolizable energy requirements and promote weight gains of $150 \mathrm{~g} /$ day, according to recommendations by NRC (1981). The quantity of feed daily supplied was adjusted according to the consumption from the previous day, allowing for leftovers around $20 \%$ of the total. This was offered so as to guarantee voluntary consumption by the animals. The animals
Table 1 - Percentage and chemical composition of the diets

\begin{tabular}{lcc}
\hline Ingredient (\%) & $\begin{array}{c}2.71 \mathrm{Mcal} / \\
\mathrm{kg} \mathrm{DM}\end{array}$ & $\begin{array}{r}2.20 \mathrm{Mcal} / \\
\mathrm{kg} \mathrm{DM}\end{array}$ \\
\hline Corn bran & 57 & 21 \\
Soy bran & 5 & 6 \\
Molasses & 1 & 1 \\
Mineral nucleus & 1 & 1 \\
Limestone & 1 & 1 \\
Maniçoba hay & 35 & 70 \\
Chemical composition (\%) & & \\
Dry matter & 89.25 & 89.85 \\
Protein & 12.23 & 12.16 \\
Metabolizable energy (Mcal/kg DM) & 2.71 & 2.20 \\
Lipids & 6.99 & 3.80 \\
Neutral detergent fiber & 40.50 & 53.09 \\
Acid detergent fiber & 20.22 & 33.46 \\
\hline
\end{tabular}

consumed an average of 3.6\% dry matter of body weight. The diets were composed by the following two forage:concentrate ratios: 35:65 and 70:30.

After the period of confinement, the animals were examined for acquisition of their biometric measurements and analyses of the following variables: height of the posterior- distance from the sacral tuberosity on the back to the extremity of the distal hind limb; chest girth - perimeter based on the inferior part of the chest and withers, passing a measuring tape behind the shoulder; rump width - distance between the trochanters of the femurs; and thorax width distance between the sides of the scapular humeral joints, according to the methodology described by Yáñes et al. (2004). Body conditions of each animal were verified by palpating the lumbar region (over the lumbar vertebrae, the muscles, and the corresponding fat) and sternum region (muscle and fat that surrounds the tip of the sternum to $10-15 \mathrm{~cm}$ over the chest) Then, the animals were classified by scores ranging from 0.0 to 5.0 , obtained from the average of the grades given from the lumbar and sternum regions.

After this procedure, the animals were submitted to a food-and-water fast for 16 hours and then slaughtered according to the requirements of the RIISPOA (Regulation of Industrial and Sanitary Inspection over Products of Animal Origin) (1952). The carcasses were then hung by the tendons on appropriate hooks, at a distance of $17 \mathrm{~cm}$ from each other and cooled in a cold store chamber at $4^{\circ} \mathrm{C}$ for 24 hours. All the carcasses were wrapped in transparent plastic bags, which are necessary for reducing the loss of superficial humidity during the refrigeration process. After cooling, according to the methodology by Osório et al. (1998), the carcasses were measured to obtain the morphometric measurements. Then the carcasses were sectioned, in a conditioned environment, to determine the yield of the 
following commercial cuts: neck, shoulder, ribs, loin and leg, according to the methodology by Silva Sobrinho et al. (2001). The weights and yields of the hot and cold carcasses, and the losses from refrigeration were evaluated. The weights of non-constituents of the carcass, edible viscera called "buchada" yield (RB \%), were determined based on the weight of the "buchada" (sum of the blood, liver, kidneys, lungs, spleen, tongue, heart, omentum, reticulorumen, omasum and small intestine) in relation to the body weight of the animal (BWA) at slaughter, RB $(\%)=[(\Sigma \mathrm{OC}(\mathrm{kg}) / \mathrm{BWA}$ $(\mathrm{kg}))] \times 100$ and of the "panelada" which aside from the "buchada", includes the feet and the head, RP $(\%)=[(\Sigma \mathrm{OC}$ + feet + head/ BWA (kg)) $] \times 100$.

The experimental design used was completely randomized, in a $2 \times 2$ (two breeds and two diets)factorial scheme, with 10 replications. The data were submitted to analysis of variance and the averages compared by the $\mathrm{F}$ test at $5 \%$ of probability (SAS, 1999).

\section{Results and Discussion}

An interaction between breed and diet was not observed $(\mathrm{P}>0.05)$ for any of the following variables analyzed in this study: biometric measurements, carcass yield, morphometric measurements, commercial cuts and non-constituent components of the carcass.

Biometric measurements did not differ between Moxotó and Canindé kids (Table 2). Results higher than those obtained for the genotypes evaluated in this research were referred to by Menezes et al. (2007), when studying Alpine goats and Bôer crossbred goats. However, these are exotic and larger breeds compared to the native ones here. Confirming this supposition, Yáñez et al. (2004), when studying Saanen kids with an average weight of $20 \mathrm{~kg}$, found values inferior to those in this research, and according to Ribeiro et al. (2004), all of the results are in accordance to the racial standard of the studied breeds.

Diet significantly influenced the rump perimeter and the corporal score, which were larger in the animals that received more energetic diets. This proves that the most energetic diets perfectly supplied the physiological needs of the animals and made the synthesis of muscle tissue and the deposition of fat in the carcass more efficient. The animals with the highest scores also presented a better carcass conformation and better yield (Table 3).

The Canindé breed kids were characterized by presenting a greater final weight, body weight after fasting, and hot and cold carcass weights compared to those of the Moxotó breed. The Canindé breed carcasses also were in evidence because of a lower loss during refrigeration, mainly due to a greater thickness of fat, since this external fat cover maintains the quality of the carcass by protecting it from dehydration (Costa et al., 2008).

Goats usually present a hot carcass yield from 39 to $54 \%$ (Anous \& Mourad, 2001), a commercial or cold carcass yield from 38 to 51\% (Dhanda et al., 2003) and a real or biological yield of 51 to 57\% (Sen et al., 2004). These variations are influenced, in general, by factors such as breed and nutritional handling.

The animals that consumed diets with a higher level of energy presented a greater final weight and conformation, as well as a greater carcass yield as a result of greater availability of metabolizable energy for the animals and for synthesis of muscle tissue. Similar results were cited by Mattos et al. (2006) in a research with Moxotó and Canindé goats.

The morphometry of the carcass permits the evaluation of the conformation in an objective way. There was no significant difference $(\mathrm{P}>0.05)$ between the morphometric measurements of the carcasses among the studied genotypes (Table 4).

Table 2 - Biometric measurements of fedlot native goats fed diets with two levels of energy

\begin{tabular}{|c|c|c|c|c|c|}
\hline \multirow[t]{2}{*}{ Variable } & \multicolumn{2}{|c|}{ Genotype } & \multicolumn{2}{|c|}{ Diets (Mcal/kg DM) } & \multirow[t]{2}{*}{ CV (\%) } \\
\hline & Moxotó & Canindé & 2.71 & 2.2 & \\
\hline New Zealand length $(\mathrm{cm})$ & 55.10 & 56.55 & 56.95 & 54.70 & 4.96 \\
\hline Spanish length $(\mathrm{cm})$ & 57.75 & 59.40 & 60.05 & 57.10 & 6.05 \\
\hline Dorsal height (cm) & 53.45 & 53.95 & 54.75 & 52.65 & 6.37 \\
\hline Hip height $(\mathrm{cm})$ & 54.95 & 56.35 & 56.50 & 54.80 & 6.15 \\
\hline Leg length (cm) & 30.95 & 31.80 & 32.15 & 30.60 & 13.20 \\
\hline Thoracic width (cm) & 15.43 & 15.88 & 16.18 & 15.13 & 10.10 \\
\hline Rump width (cm) & 15.10 & 15.45 & 15.65 & 14.90 & 10.66 \\
\hline Thoracic perimeter $(\mathrm{cm})$ & 74.35 & 76.05 & 77.00 & 73.40 & 5.80 \\
\hline Thigh perimeter $(\mathrm{cm})$ & 36.20 & 36.60 & 38.45 & 34.35 & 13.22 \\
\hline Rump perimeter (cm) & 65.23 & 70.35 & $72.25 \mathrm{~A}$ & 63.33B & 15.19 \\
\hline Leg length $(\mathrm{cm})$ & 47.75 & 48.30 & 48.85 & 47.20 & 6.74 \\
\hline Score $(1-5)$ & 3.33 & 3.50 & $3.83 \mathrm{~A}$ & $3.00 \mathrm{~B}$ & 23.32 \\
\hline
\end{tabular}

Averages followed by different letters on the lines differ by the $\mathrm{F}$ test at $5 \%$ probability. $\mathrm{CV}=$ coefficient of variation. 
Table 3 - Carcass yield and coefficient of variance of confined goats fed with two levels of energy

\begin{tabular}{|c|c|c|c|c|c|}
\hline \multirow[t]{2}{*}{ Variables } & \multicolumn{2}{|c|}{ Genotype } & \multicolumn{2}{|c|}{ Diets (Mcal/kg DM) } & \multirow[t]{2}{*}{ CV (\%) } \\
\hline & Moxotó & Canindé & 2.71 & 2.2 & \\
\hline Initial weight (kg) & 15.29 & 15.15 & 15.46 & 14.97 & 13.47 \\
\hline Final weight (kg) & $19.96 \mathrm{~b}$ & $21.65 a$ & $22.88 \mathrm{~A}$ & $18.73 \mathrm{~B}$ & 11.36 \\
\hline Live weight after fast (kg) & $18.81 b$ & $20.49 a$ & $21.74 \mathrm{~A}$ & $17.57 \mathrm{~B}$ & 10.68 \\
\hline$\%$ Loss after fast & 5.73 & 5.31 & 4.91 & 6.12 & 46.00 \\
\hline Weight of hot carcass (kg) & $8.77 b$ & $9.87 \mathrm{a}$ & $10.83 \mathrm{~A}$ & $7.81 \mathrm{~B}$ & 13.91 \\
\hline Hot carcass yield (\%) & 46.42 & 47.62 & 49.69A & $44.34 \mathrm{~B}$ & 5.91 \\
\hline Cold carcass weight (kg) & $8.44 b$ & $9.64 a$ & $10.53 \mathrm{~A}$ & $7.55 B$ & 14.11 \\
\hline Cold carcass yield (\%) & 44.59 & 46.51 & $48.33 \mathrm{~A}$ & $42.78 \mathrm{~B}$ & 5.71 \\
\hline Loss from refrigeration (\%) & 3.93b & $2.30 \mathrm{a}$ & 2.74 & 3.48 & 52.89 \\
\hline Empty body weight (kg) & $15.87 b$ & $17.49 \mathrm{a}$ & $18.93 \mathrm{~A}$ & $14.42 \mathrm{~B}$ & 12.09 \\
\hline Biological yielding (\%) & 55.25 & 55.95 & $57.10 \mathrm{~A}$ & $54.09 B$ & 4.72 \\
\hline Thickness of fat $(\mathrm{cm})$ & $0.87 \mathrm{~b}$ & $1.01 \mathrm{a}$ & 1.02 & 0.86 & 3.45 \\
\hline Carcass conformation (1-5) & $3.03 \mathrm{~b}$ & $3.38 a$ & $3.50 \mathrm{~A}$ & $2.90 \mathrm{~B}$ & 23.77 \\
\hline
\end{tabular}

Averages followed by different letters on the lines differ by the $\mathrm{F}$ test at $5 \%$ probability. Lowercase letters refer to breeds and uppercase letters to diet.

$\mathrm{CV}=$ coefficient of variation.

Table 4 - Morphometric measurements and coefficient of variation of goats fed two levels of energy

\begin{tabular}{|c|c|c|c|c|c|}
\hline \multirow[t]{2}{*}{ Variable } & \multicolumn{2}{|c|}{ Genotype } & \multicolumn{2}{|c|}{ Diets (Mcal/kg DM) } & \multirow[t]{2}{*}{ CV (\%) } \\
\hline & Moxotó & Canindé & 2.71 & 2.2 & \\
\hline New Zealand length (cm) & 59.28 & 61.93 & 61.98 & 59.23 & 7.09 \\
\hline Spanish length $(\mathrm{cm})$ & 47.63 & 49.80 & 49.93 & 47.50 & 4.77 \\
\hline Internal length of the carcass $(\mathrm{cm})$ & 56.50 & 58.53 & $59.40 \mathrm{~A}$ & $55.63 B$ & 6.10 \\
\hline Leg length $(\mathrm{cm})$ & 32.35 & 32.48 & 33.23 & 31.60 & 7.14 \\
\hline Thigh perimeter $(\mathrm{cm})$ & 27.08 & 28.30 & 28.48 & 26.90 & 8.90 \\
\hline Rump perimeter (cm) & 41.50 & 42.68 & $44.30 \mathrm{~A}$ & $39.88 B$ & 7.60 \\
\hline Maximum width of the rump (cm) & 17.75 & 17.83 & 18.03 & 17.55 & 7.95 \\
\hline Minimum width of the rump $(\mathrm{cm})$ & 13.63 & 13.70 & 14.08 & 13.25 & 10.17 \\
\hline Thoracic perimeter $(\mathrm{cm})$ & 60.25 & 60.53 & $63.05 \mathrm{~A}$ & $57.73 \mathrm{~B}$ & 4.30 \\
\hline Thoracic depth (cm) & 24.58 & 24.93 & $25.53 \mathrm{~A}$ & $23.98 \mathrm{~B}$ & 3.93 \\
\hline Maximum width of the thorax $(\mathrm{cm})$ & 13.13 & 13.48 & 13.83 & 12.78 & 15.01 \\
\hline
\end{tabular}

Averages followed by different letters on the lines differ by the F test at 5\% probability. Lowercase letters refer to breeds and uppercase letters to diet.

$\mathrm{CV}=$ coefficient of variation.

The levels of energy used in the feed had a very significant effect on the internal length of the carcass, on the rump perimeter, and on the thoracic perimeter and depth because those results were always better in the carcasses of the goats that received the diets with the most energy. These results can be justified by the fact that the consumed food is transformed into energy and this energy, when in excess, is transformed into meat and fat. The presence of these components in the carcass tends to increase the measurements analyzed in this work. Yáñez et al. (2004), studying food restrictions in Saanen goats, verified that the measurements in the animals that did not receive food restrictions were greater than in those kids which were submitted to a food restriction of up to $60 \%$ of their diet: for internal length of the carcass, 64.5 and $59.2 \mathrm{~cm}$; width of the rump, 14 and $12 \mathrm{~cm}$; thoracic perimeter, 68.8 and $60.4 \mathrm{~cm}$, and thoracic depth 26 and $24 \mathrm{~cm}$.

Based on the absolute values of the commercial cuts (Table 5), the Canindé breed can be classified as being of superior quality when compared to Moxotó breed animals.

Expected results were obtained by using more energetic diets. However, considering the percentage values of the commercial cuts, a difference between the diets was not observed. These data reinforce the information present in the law of anatomical harmony (Siqueira et al., 2001). According to this law, in carcasses with similar weights and quantities of fat, a significant part of the body regions presents similar proportions, regardless to the conformation of the considered genotypes. The analysis of the commercial cuts in the carcass permits a qualitative evaluation of these cuts and enables the choice of diets which will lead to the attainment of cuts of greater interest to the consumer (Yáñez et al., 2004).

Diet acted as the main factor influencing (Table 6) the non-constituent components of the carcasses of goats from the Moxotó and Canindé breeds. The influence of the level of energy on the weight of the organs that were 
Table 5 - Weights and percentages of the commercial cuts and coefficient of variation of native goats fed two levels of energy

\begin{tabular}{|c|c|c|c|c|c|}
\hline \multirow[t]{2}{*}{ Variable (kg) } & \multicolumn{2}{|c|}{ Genotype } & \multicolumn{2}{|c|}{ Diets (Mcal/kg DM) } & \multirow[t]{2}{*}{ CV (\%) } \\
\hline & Moxotó & Canindé & 2.71 & 2.2 & \\
\hline Half carcass weight & $3.94 b$ & $4.48 \mathrm{a}$ & $4.85 \mathrm{~A}$ & $3.57 \mathrm{~B}$ & 14.10 \\
\hline Shoulder & $0.85 b$ & $0.95 a$ & $1.03 \mathrm{~A}$ & $0.77 \mathrm{~B}$ & 17.47 \\
\hline Leg & $1.24 \mathrm{~b}$ & $1.41 \mathrm{a}$ & $1.50 \mathrm{~A}$ & $1.15 \mathrm{~B}$ & 14.75 \\
\hline Neck & 0.38 & 0.39 & $0.43 \mathrm{~A}$ & $0.34 \mathrm{~B}$ & 23.37 \\
\hline Loin & $0.42 b$ & $0.52 \mathrm{a}$ & $0.56 \mathrm{~A}$ & $0.39 B$ & 21.82 \\
\hline \multicolumn{6}{|l|}{ Variables (\%) } \\
\hline Shoulder & 21.4 & 21.2 & 21.26 & 21.44 & 7.85 \\
\hline Leg & 31.54 & 31.58 & 32.17 & 30.95 & 7.38 \\
\hline Neck & $9.5 b$ & $8.6 \mathrm{a}$ & 8.76 & 9.47 & 17.13 \\
\hline Loin & 10.71 & 11.69 & 11.39 & 11.00 & 15.41 \\
\hline Sidecut & 26.55 & 26.62 & 27.44 & 25.74 & 9.31 \\
\hline
\end{tabular}

Averages followed by different letters on the lines differ by the $\mathrm{F}$ test at $5 \%$ probability. Lowercase letters refer to breeds and uppercase letters to diet. $\mathrm{CV}=$ coefficient of variation.

Table 6 - Non-constituent components of the carcass and coefficient of variation of native goats fed different levels of energy

\begin{tabular}{|c|c|c|c|c|c|}
\hline \multirow[t]{2}{*}{ Variable } & \multicolumn{2}{|c|}{ Genotype } & \multicolumn{2}{|c|}{ Diets (Mcal/kg DM) } & \multirow[t]{2}{*}{ CV (\%) } \\
\hline & Moxotó & Canindé & 2.71 & 2.2 & \\
\hline Empty body weight (kg) & 15.87 & 17.49 & $18.93 \mathrm{~A}$ & $14.42 \mathrm{~B}$ & 12.09 \\
\hline Lungs (kg) & $0.16 \mathrm{~b}$ & $0.19 a$ & 0.18 & 0.17 & 21.26 \\
\hline Diaphragms (kg) & 0.05 & 0.06 & 0.06 & 0.05 & 28.10 \\
\hline Trachea+esophagus (kg) & 0.10 & 0.09 & 0.10 & 0.09 & 21.04 \\
\hline Heart (kg) & 0.09 & 0.10 & $0.10 \mathrm{~A}$ & $0.08 \mathrm{~B}$ & 18.29 \\
\hline Tongue (kg) & 0.07 & 0.07 & 0.07 & 0.07 & 17.34 \\
\hline Pancreas (kg) & 0.04 & 0.04 & $0.05 \mathrm{~A}$ & $0.03 B$ & 38.8 \\
\hline Liver (kg) & 0.29 & 0.32 & $0.34 \mathrm{~A}$ & $0.27 \mathrm{~B}$ & 17.59 \\
\hline Kidneys (kg) & 0.06 & 0.06 & $0.06 \mathrm{~A}$ & $0.05 B$ & 12.39 \\
\hline Full gastrointestinal tract (kg) & 4.36 & 4.47 & 4.37 & 4.46 & 14.17 \\
\hline Empty gastrointestinal tract (kg) & 1.41 & 1.47 & 1.57 & 1.31 & 21.41 \\
\hline Gastrointestinal content(kg) & 2.95 & 3.00 & 2.81 & 3.14 & 19.64 \\
\hline Mesenteric fat (kg) & 0.16 & 0.17 & $0.21 \mathrm{~A}$ & $0.12 \mathrm{~B}$ & 55.36 \\
\hline Perirenal fat (kg) & 0.37 & 0.41 & $0.53 \mathrm{~A}$ & $0.25 B$ & 63.30 \\
\hline Head (kg) & 1.32 & 1.26 & $1.36 \mathrm{~A}$ & $1.23 \mathrm{~B}$ & 11.37 \\
\hline Hoofs (kg) & 0.52 & 0.56 & $0.60 \mathrm{~A}$ & $0.48 \mathrm{~B}$ & 8.93 \\
\hline Skin (kg) & 1.25 & 1.25 & $1.36 \mathrm{~A}$ & 1.14B & 15.06 \\
\hline "Buchada" yield (\%) & 18.27 & 18.58 & 18.85 & 18.01 & 11.99 \\
\hline “Panelada” yield (\%) & 28.11 & 27.53 & 27.89 & 27.75 & 8.30 \\
\hline
\end{tabular}

Averages followed by different letters on the lines differ by the F test at $5 \%$ probability. Lowercase letters refer to breeds and uppercase letters to diet.

$\mathrm{CV}=$ coefficient of variation .

classified as having precocious growth, such as heart, liver, lungs and kidneys, probably happened because of a higher consumption by the animals, enabling a greater contribution of nutrients and increasing the metabolic rate. The quantity of food ingested during the experimental period was responsible for a greater development of the gastrointestinal tract, which dilates according to the volume ingested.

Mattos et al. (2006), evaluating food restriction for Moxotó and Canindé goats, obtained similar conclusions. In the animals which did not have any food restrictions, the nonconstituent components of the carcasses were heavier than in the animals with $30 \%$ restriction in their restricted feed.

\section{Conclusions}

In the Canindé breed, the quantitative characteristics of the carcass are superior to those from the Moxotó breed. The supplying of diets with higher levels of energy for Moxotó and Canindé breed goats in feedlots favors the production of carcasses with superior yields and heavier commercial cuts.

\section{References}

AlMEIDA JR., G.A.C.; MONTEIRO, A.L.G.; GARCIA,C.A. et al. Desempenho, características de carcaça e resultado econômico de cordeiros criados em creep feeding com silagem de grãos úmidos 
de milho. Revista Brasileira de Zootecnia, v.33, n.4, p.1048-1059, 2004.

ANOUS, M.R.; MOURAD, M. Some carcass characteristics of Alpine kids under intensive versus semi-intensive systems of production in France. Small Ruminant Research, v.40, p.193-196, 2001.

CARTAXO, F.Q.; CEZAR, M.F.; SOUSA, W.H. et al. Características quantitativas da carcaça de cordeiros terminados em confinamento e abatidos em diferentes condicões corporais. Revista Brasileira de Zootecnia, v.38, n.4, p.697-704, 2009.

COSTA, R.G.; MEDEIROS, A.N.; SANTOS, N.M. et al. Carcass quality of Saanen goats fed different levels of roughage and concentrate. Revista Brasileira de Ciências Agrárias, v.3, n.2, p.186-190, 2008.

DHANDA, J.S.; TAYLOR, D.G.; MURRAY, P.J. Part 1. Growth,carcass and meat quality parameters of male goats: effects of genotype and liveweight at slaughter. Small Ruminant Research, v.50, n.6, p.57-66, 2003.

MATTOS, C.W.; CARVALHO, F.F.R.; DUTRA JR., W.M. et al. Characteristics of carcass and non-carcass components of kids and Moxotó Canindé under two levels of feeding. Revista Brasileira de Zootecnia, v.35, n.5, p.2125-2134, 2006.

MENEZES, J.J.L.; GONÇALVES, H.C.; RIBEIRO, M.S. et al. Performance and biometric measurements of goats of different racial groups. Revista Brasileira de Zootecnia, v.36, n.3, p.635-642, 2007.

MORON-FUENMAYOR, O.E.; CLAVERO, T. The effect of feeding system on carcass characteristics, non-carcass components and retail cut percentages of lambs. Small Ruminant Research, v.34, n.1, p.57-64, 1999.
NATIONAL RESEARCH COUNCIL - NRC. Nutrient requirement of domestics animals: nutrient requirement of goats. Washington, D.C., 1981. 91p.

OSÓRIO, J.C.S.; OSÓRIO, M.T.M.; JARDIM, P.O.C. et al. Methods to evaluate the production of mutton, "in vivo" in carcass and meat. Pelotas: Ed. UFPEL, 1998. 107p.

REGULATION OF INDUSTRIAL AND SANITARY INSPECTION OF ANIMAL PRODUCTS - RIISPOA. Establishment and derivatives. Chapter I, Lei no 1283, Decree 30691, 1952. 4p.

RIBEIRO, M.N.; GOMES FILHO, M.A.; BERMEJO, J.V.D. et al. Conservation of native breeds of goats in Brazil: History, current status and prospects. Publisher: Maria Norma- Recife: UFRPE, Imprensa Universitária, 2004. 62p.

SEN, A.R.; SANTRA, A.; KARIM, S.A. Carcass yield, composition and meat quality attributes of sheep and goat under semiarid conditions. Meat Science, v.66, n.7 p.757-763, 2004.

SILVA SOBRINHO, A.G.; GONZAGA NETO, S. Meat goat production and housing courts. Jaboticabal: FCAV, 2001. 17p.

SIQUEIRA E.R.; SIMÕES, C.D.; FERNANDES, S. Effect of sex and slaughter weight on the production of lamb meat. Morphometry of the carcass weights of cuts, tissue composition and components are constituents of the carcass. Revista Brasileira de Zootecnia, v.30, n.4, p.1299-1307, 2001.

STATISTICAL ANALYSES SYSTEM - SAS. User's guide: statistics. Version 8 (TS MO). Cary: 1999. (CD-ROM).

YÁÑEZ, E.A.; RESENDE, K.T.; FERREIRA, A.C.D. et al. Using biometric measurements to predict carcass characteristics of Saanen goats. Revista Brasileira de Zootecnia, v.33, n.6, p.1564-1572, 2004. 